\title{
Hope and a horizon of solidarity - An interview with Jeffrey $C$. Alexander
}

\author{
Interviewed by Anna Lund and Andrea Voyer
}

\begin{abstract}
In this interview, Jeffrey C. Alexander describes the development of cultural sociology, the importance of collaborative work, and the inspiration he takes from his political action, and from the art and humanities. The interview focuses primarily on civil sphere theory (CST), and Alexander's goal in moving towards Durkheimian and away from Parsonian conceptions of solidarity. Alexander addresses common misunderstandings and critiques of CST, describes the current project of the internationalization of CST, and applies the theory to the present crisis of a global pandemic and the social movement of Black Lives Matter. Finally, Alexander reflects upon life in the academic world and the importance of not only analyzing meaning as a cultural sociologist but also working with meaningful projects in order to not be alienated. Alexander was invited keynote speaker at the Sociologidagarna in March in Stockholm 2020, but due to the Corona pandemic the conference was cancelled. This interview took place through Zoom in three different locations (Stockholm, New Haven, and Coventry, Connecticut) on 22 June 2020.

Keywords: Jeffrey C. Alexander, Cultural sociology, Civil sphere theory, Meaning, Black Lives Matter, COVID-19
\end{abstract}

JefFrey C. Alexander is the Lillian Chavenson Saden Professor of Sociology at Yale University, USA, where he established the Center for Cultural Sociology (CCS) with Philip Smith and Ron Eyerman. He is one of the founders of the journal American Journal of Cultural Sociology. He has published more than twenty books and edited another thirty more, along with hundreds of articles. After publishing Theoretical logic in sociology in the early 1980s, and leaving neo-functionalism shortly after, he began to develop a meaning-oriented cultural sociology, creating research programs in trauma theory ${ }^{1}$, performance theory ${ }^{2}$, and civil sphere theory ${ }^{3}$. Currently, expanding on work from a decade ago, he is developing a new research program on iconicity. Among the

1 Alexander, J.C., R. Eyerman, B. Giesen, N.J. Smelser \& P. Sztompka (2004) Cultural trauma and collective identity. Berkeley: University of California Press.

2 Alexander J.C. (2004) "Cultural pragmatics: Social performance between ritual and strategy", Sociological Theory 22 (4):527-573. https://doi.org/10.1111/j.0735-2751.2004.00233.x

3 Alexander, J.C. (2006) The civil sphere. Oxford: Oxford University Press. 
most recent projects he has been engaged in is an internationalization of the civil sphere theory through several civil sphere conferences followed by edited volumes ${ }^{4}$.

ANNA LUND IS a professor of sociology at the Department of Sociology, Stockholm University. Cultural sociological perspectives and ethnographic methods characterize her research, as well as a theoretical concern with social change and cultural transformation under conditions of adversity. Her current research interest is connected to how modes of incorporation is performed in school settings among and for migrant students as well as in Swedish children's theater. She employs civil sphere theory at the microlevel by investigating interactional and organizational processes in school and theater contexts.

ANdrea voyer is an Associate Professor (docent) at the Department of Sociology, Stockholm University. Voyer is a cultural sociologist whose research focuses on meaning and its impact on processes of social inclusion and exclusion on the basis of immigration, race, and class. She uses qualitative and computational sociological methods in her research. Prior to joining the faculty of Stockholm University, Voyer was a Russell Sage Foundation Visiting Scholar and an Assistant Professor of Sociology at the University of Connecticut, USA. She received her Ph.D. from the University of Wisconsin-Madison, USA.

\section{Cultural sociology as a collaborative project}

Anna Lund [AL]: Over the years, you have built a research milieu and the weekly workshop in cultural sociology. How do you see social theory in relation to building a research environment? Do you see social theory as a collaborative project?

Jeffrey Alexander [JA]: Yes and no. On the one hand, I'm very aware that my own theorizing is occurring in a place inside of my own mind. It's an unconscious creative process that's developed over 40 years. I'm aware of that process, but I never know where it's going to go. So, in that sense social theory is from each person - it comes out of themselves. But in my own life, at least from the beginning of cultural sociology, which for me was in the mid-eighties, it is always collaborative. Everything has developed in conversation with, at first, students, and then colleagues. I can't imagine my ideas developing without that continuous dialogue.

At UCLA [in 1984], I started this thing called the Culture Club before I even knew what cultural sociology was exactly. I knew that we would be bringing in hermeneutics and semiotics, but there was no cultural sociology at that time, so I only assigned things

4 Alexander, J.C. \& C. Tognato (2018) The civil sphere in Latin America. Cambridge: Cambridge University Press.; Alexander, J.C. (2019) The civil sphere in East Asia. Cambridge: Cambridge University Press; Alexander, J.C., A. Lund \& A. Voyer (2019). The Nordic civilsphere. Cambridge: Polity Press. 
from outside of the discipline of sociology. We would read anthropology, semiotics, narrative theory, history and, of course, Clifford Geertz and Foucault. Those conversations with such early students as Anne Kane, Eric Rambo, Elaine Chan, Agnes Ku, and Steven Sherwood were crucial. Elaine and Eric, for example, wrote a review essay on the sociology of culture in 1990, in which they gave the term "culture structures" center place 5 . We had used the term culture structures a lot in our Culture Club discussions but it had never been published. This was a great feeling, that they had done this, getting our new sensibility published in a good journal. We felt that we were making something as we were going along.

My students always gave me new ideas, and sometimes giant ones. Phil Smith was critical in helping provide a rich empirical elaboration of the skeleton essay I wrote on the discourse of civil society, and he did the same incredible work on our foundational essay on structural hermeneutics. ${ }^{6}$ Jason Mast came in the 1990s. He tried to apply the Watergate ritual model to the Clinton impeachment. ${ }^{7}$ He said, "It doesn't work. Jeff, nothing you said happened with Nixon, happened with Clinton." and I said, "But Jason, I didn't say it had to happen. I pointed to contingencies," and we had this ongoing discussion. Then, in the summer of 2000, I said, "Jason I'm going to think of a new model." I started thinking about performance, which is a much more contingent understanding of symbolic processes, and decided to get completely away from ritual. I realized that the idea of a ritual, even if you think of it as a contingent ritual, is way too constricting. It was time to get new ideas.

Moving to Yale, the Culture Club became like a public sphere, and my own perspective on cultural sociology continued to develop. In 2003, I published the book The meanings of social life, which brought together essays that I had published, often very obscurely, since the 1980s Culture Club days, but there was an emergent phenomenon here, and the time was evidently right, because the book soon came to be regarded as creating a new paradigm, a way of doing cultural sociology. The first meeting of CCS (Center for Cultural Sociology) was probably in fall 2002 or spring 2003. There were about a half a dozen of us, and we'd invite people from Yale humanities and other cultural thinkers from outside Yale to make presentations. Over the next 20 years, CCS became a kind of "group mind" experience. Two things happened. On the one hand, without knowing it, the group created a culture of discourse and respect, and a protected space where people could ask hard questions even if they were just beginning their academic careers. And, on the other hand, they also felt that they were involved in a common project together, such that they would never have to justify a strongly

5 Rambo, E. \& E. Chan (1990) “Text, structure, and action in cultural sociology", Theory and Society 19 (5):635-648. https://doi.org/10.1007/BF00147029

6 Alexander, J. \& P. Smith (2001) "The strong program in cultural theory: Elements of a structural hermeneutics", 135-150 in J.H. Turner (Ed.) Handbook of sociological theory. Boston: Springer. https://doi.org/10.1007/0-387-36274-6_7

7 Alexander, J.C. (1988) "Culture and political crisis: Watergate and Durkheimian sociology", 187-224 in J.C Alexander (Ed.) Durkheimian sociology: Cultural studies. Cambridge: Cambridge University Press. 
cultural sociology. This opened up what had been a little club at UCLA, expanding it into a big society, and eventually a global network of conversation. It became a very wide dialogue among many, many people across the world. The weekly Friday workshops felt less like an academic seminar and more like "collective thinking," working through new pathways for and fundamental questions about cultural sociology. And, throughout this time, I was collaborating with individual doctoral students - their particular interests, their concerns, their ideas. Working with doctoral students is always a going back and forth that enriches both of us.

Throughout this period, I was also engaged in intimate collaboration with colleagues who had never been my students. Without Bernhard Giesen, Ron Eyerman, and Piotr Sztompka, there would have been no cultural trauma theory. Years earlier, Bernhard and I gave one another reassurance at a critical moment of intellectual transition from neo-functionalism to semiotics. Years later, we worked together, along with our doctoral students, on the emerging theory of social performance.

The civil sphere conferences are the culmination of these experiences of collaboration. They are extraordinary because I organized each of them by depending completely on people I already knew, like the two of you for The Nordic civil sphere, or two former students for the East Asian civil sphere. They, in turn, would suggest a dozen or so sociologists whom I didn't know. Then there'd be this long, long process of proposals, feedback on the proposals, and asking for revision. Then the two-day conferences, filled with a lot of intense dialogue. When, at the end of these long sequences, I would write (usually co-write) the introductions to each civil sphere volume, what came out in these essays was nothing like what I would have ever been able to think through by myself. These learning experiences were truly gratifying, the epitome of a collegial experience.

\section{Civil sphere theory}

$A L$ : What if sociologists never heard of CST? How would you explain it?

$J A$ : I think we all have the idea, all of us in all societies, whether it's China or Sweden or India or Colombia, of a horizon of solidarity with everybody who's in what Geertz called the "terminal community." We have this feeling that everybody is the same kind of human being, or at least has the potential to become fully human. It's a sense that we know who the people in our society are, as either types of people or individuals we actually could know and understand. I wanted to find a way of crystallizing this feeling conceptually. What I came eventually to realize is that these feelings actually constitute an organized social world, that there's actually this sphere. There's not just an economy, a church, a family, a legal order, a state, and a market. There's also this other thing, and we'll call it the civil sphere. We relate it to solidarity. After I first crystallized this idea, I realized that it had rarely been talked about. But I also realized that this new intellectual idea was a way of having hope. It was a way of trying to bring what philosophers call a normative dimension into a sociological concept in order to 
highlight horizontal as compared to (what sociologists usually concentrate on) vertical relationships. Citizenship is a term that means to capture this, too, but it is to me a very thin idea because it refers primarily to a legal, state-accorded status, although T.H. Marshall ${ }^{8}$ did wonderfully theorize other political and especially social levels. I wanted to find a concept, a theory, and a model that, on the one hand, would articulate this subjective sensibility for the first time, that we're connected to other people and that we're all in this together, and I wanted to connect to the notion of justice. I often had a working title for The civil sphere, which was Justice - a take-off on Rawls' book, A theory of justice. ' How could these subjective and normative things be transformed into a rigorous, "realistic" sociological theory that made empirical statements and not normative ones, but built the normative hopes and aspirations of social actors into the theory? That was the challenge.

\section{$A L:$ Where did you get your inspiration?}

$J A$ : Partly from a life spent as a politically-involved person. Partly from objectifying my own individual consciousness. I had always cared passionately about social injustice, as so many of us do. But then I wondered, "Well, what exactly, in sociological terms, have I been caring about all this time? What have I been working for?” My parents were very moved by the civil rights movement in the 1950s and 1960s. During the Lyndon B. Johnson days, I worked for his "Great Society" program for the summer of 1966, as a social worker in Watts, the African-American ghetto in Los Angeles. I was also very active as an anti-war activist. I was in SDS (Students for a Democratic Society) as an undergraduate at Harvard and in March 1969, when the campus came to a halt after the SDS building takeover, I was elected to the Harvard Strike Steering Committee. As a doctoral student at Berkeley, I organized, alongside others, anti-war and pro-working class campaigns in a working class suburb and a trade union organizing hall. In the 1980s, at UCLA, I worked with a group called "Concerned Faculty," staging teach-ins against Reagan's Central American interventions and massive rallies against Apartheid. Such experiences constituted the personal inputs to my later creation of CST. But then, of course, there were the decisive intellectual ones. After I gave up Marxism in the early 1970 s, I fell in love with Durkheim and interpreted a new, "late" focus in his work. Durkheim is Mr. Solidarity, and I was acutely aware that this concept had more or less disappeared from modern social theory. Parsons had developed the notion of the societal community, certainly related to Durkheim's notion of society and solidarity, but Parsons hadn't connected it to issues of justice and injustice, so his thinking about community didn't stretch to the dynamic, intense, and complex tension that exists between hopes for an expanded solidarity and social hierarchies of various kinds. But I did think that something like a "societal community" would be a great idea, if it could ever exist! Somebody once asked Gandhi, "What do you think of Western civiliza-

8 Marshall, T.H. (1964) Class, citizenship, and social development: Essays. New York: Doubleday.

9 Rawls, J. (2005[1971]) A theory of justice. Cambridge, Massachusetts: Harvard University Press. 
tion?" and Gandhi said, "I think it would be a good idea!" As a relatively conservative liberal, Parsons believed that it already existed, whereas my sense was that it had yet to be made, at least more fully made; hence, the civil sphere is a project. I went to China in May 1989, taught a course at Tianjin for a month, about sociological theories of democracy, and left the day that Tiananmen started. Returning to UCLA, I was obsessed with the Tiananmen struggles. I had been reading Foucault with Adam Seligman, who was visiting for the year, and when I told him that modern sociology had no way to conceptualize what was going on in China, Adam mentioned that there'd actually been a resurgence of writing about civil society in relation to the transition from communism and from authoritarianism in Latin America. I wasn't aware of this recent resurgence. For me civil society was a concept in the history of political thought, which I'd studied at Harvard - Locke, Tocqueville, Mill, and Hegel. After that, when I became a "New Left Marxist," I discovered the cultural Marxism of Gramsci, who had studied with Labriola, the Italian Hegelian-Marxist. I was immediately taken by Gramsci's understanding of bourgeois civil society as a cultural field, inside of which unfolded a struggle for ideological hegemony. As I was leaving Marxism behind, I wrote a paper for Leo Löwenthal synthesizing Durkheim and Gramsci, and never left behind the idea that civil society was cultural. As I started reading the new civil society theorizing in the fall of ' 89 after coming back from China, everything crystallized, and I very quickly wrote an essay on the civil sphere, in which, over about a hundred pages, I first formulated my ideas of a binary civil discourse at the core of a structure, always fragmented and partial, of a powerful solidarity. The British political theorist David Held was visiting UCLA at the time, and he was one of the troika of editors of Polity Press. I remember David saying, "I want to publish this essay right as it is." and I said, "Well, I just need a little more work on it." Seventeen years later, I published it.

Andrea Voyer [AV]: What are some common misunderstandings or critiques of civil sphere theory and how do you address them?

$J A$ : The most common misunderstanding and critique is that I think that we have a civil sphere that's great and that I think everything's perfect - that I'm reading civil society as a Parsonian. Parsons was really brilliant, but also extremely irritating in terms of his rather enthusiastic, whiggish endorsement of the modern US and his broadly Pollyannaish understanding of what he called "the system of modern society." The civil sphere was written, implicitly, as a refutation of this Parsonian way of thinking. So, there is a misunderstanding that Alexander thinks that we have a wonderful community of solidarity. I keep reminding people to look at chapter eight, "Contradictions: Uncivilizing pressures and civil repair." The whole point of the book is to look at the contradictions. I developed the theory to talk about hope as a possibility, and about justice as a possibility, not as an already achieved reality. My personal and political life, my life as a person, not just as a thinker, has been involved, and has evolved with, the movements for peace, racial justice, and feminism. Those movements and then, later, the gay and lesbian movement have been at the core of my political consciousness. I 
think these movements have been hugely consequential in creating social betterment and civil repair. At the same time, justice, for these movements and others, is always a continuing project. Which is why I developed a theory of the challenges that are posed to the civil sphere by the anti-civil strains generated by time, place, and function. The civil sphere has never been able to institutionalize the ideal of justice, it is always a search, always a possibility. So, in this sense, there's an element of the Marx-Hegel dialectical thinking that left a big impression on me, and remains at the core of CST. What I learned in my Marxism period, which for me meant a lot of reading Hegel (in Berkeley I took classes with a radical philosopher named Richard Lichtman), was the idea of continuous strain, continuous dialectics, and continuous developing. Every thesis is contradicted by an antithesis, every new synthesis is always unsettled, becoming a new thesis to be contradicted by historical development once again.

The other thing that irritated and upset me in the initial reception of CST was the notion that civil sphere theory is just about the United States. I conceptualized CST, in the first two parts of the book, as a universal theory without reference to time and place; yet, no denying it, most of my empirical examples in all four parts of the book were drawn from the United States - my treatments of French feminism and European anti-Semitism excepted. So, I could see why some readers got the impression CST was a theory about the US, and it was this understanding that triggered the still ongoing international collaboration on civil sphere theory. Throughout this years-long project, I have collaborated very closely with Peter Kivisto (Augustana College) and Giuseppe Sciortino (Trento University), who with Carlo Tognato (National University of Bogota, now at George Washington University) have been central to the elaboration of CST as a research program.

$A L$ : I was reading a recently published article in Sociological Theory by Ricarda Hammer, she critiques CST for not being sensitive enough to colonial power structures and says that there are colonial layers of meaning embedded in the civil discourse itself. ${ }^{10}$ What is your response to this critique?

$J A$ : There is, of course, a wide range of "critical theory", and/but CST is not "critical theory" in the same way. I would define "critical theory" as an approach that sees a fundamental, likely irresolvable contradiction inside of modernity. The first such critical theory was formulated by Marx, who argued that inside of capitalism class cannot be overcome and that democracy is therefore merely formal, that the class contradiction can only be resolved via revolution. Critical race theories argue that the West, but especially the US, is a "racial system," fundamentally and foundationally racist, such that race holds the same theoretical position as class does in Marxism. Some forms of feminist theory are "critical" in the same way. Critical theories of

10 Hammer, R. (2020) "Decolonizing the civil sphere: The politics of difference, imperial erasures, and theorizing from history", Sociological Theory, published online. https://doi.org/10.1177/0735275120921215 
race and gender have been among the most creative and important theorizing over the last 30 years, as Steven Seidman and I argued in our "Introduction" to The new social theory reader. ${ }^{11}$ Postcolonial theory is part of this new critical social theorizing. Starting with Edward Said's brilliant work ${ }^{12}$, there's been a vital new understanding among intellectuals in the West, which has gradually allowed us to put Western society in a different global and historical context. (I think that S.N. Eisenstadt's theory of "multiple modernities," 13 based in his and Bellah's reworking of what Jaspers called the Axial Age theory in Weber's comparative sociology of religion, were also responses, like Said's, to the growing reflexivity about Western imperialism.)

Despite their significance, however, I do not take these "critical theories" - race, gender, or post-colonial - at face value. They have a powerful truth, but only in part. Each of them points to a powerful injustice, an oppressive, anti-civil social and historical fact, which represent what I eventually theorized as contradictions in real existing civil spheres. As I developed CST, I sought to conceptually encompass these anti-justice elements as contradictions generated by time, place, and function, the latter of which focused attention on the non-civil boundaries of the civil sphere, for example the capitalist market economy which produces its class hierarchy, or the familial sphere which produces patriarchal hierarchy, or the founding groups of actually existing civil spheres who insist on equating civil capacities with their own particular primordial qualities - like whiteness and Northwestern European ethnicity in the US.

Another problem with these "critical" theories, from my point of view, is that they don't recognize the self-critical capacities of a society that are provided by the existence of even fragmented civil spheres - to develop a reflexive critique of their own anti-civil forms of hierarchical domination. Such reflexive capacity is, in a sense, concentrated by democratic self-government, which allows progressive social movements to emerge and new governments that can initiate far-reaching civil repair. There is a real danger, it seems to me, in each of the strong "critical theories," which portray society as if it consisted purely of domination along the particular dimension they identify, such that only two possibilities for change exist: revolution or exit, both of which would purportedly create an ideal society without contradictions. Thus, strong race and gender theories, proposing exit, suggest separating race into different geographical spaces, as the only way racism could be avoided, or creating a separate society for women. While I don't think Judaism generated a "critical theory" in the same sense, Zionism has similarities. In reaction to the horrifying European anti-Semitism of the 1880 s and 1890s, Zionist thinkers argued that Jews could never become incorporated into Western society, suggesting it was foundationally anti-Semitic. Because Western society was defined by the hierarchy Christian over Jew, the only option was to create a separate society made up only of Jews.

In some part, I tried to construct civil sphere theory against such "critical" theories

11 Alexander, J.C. \& S. Seidman (2008) The new social theory reader. New York: Routledge.

12 Said, E.W. (1978) Orientalism. London: Routledge \& Kegan Paul.

13 Eisenstadt, S.N. (2000) "Multiple modernities", Daedalus 129 (1):1-29. 
of fundamental and irredeemable contradictions, even as I tried to incorporate critical arguments that documented the extraordinary inequalities and sufferings that have been built into actually existing civil spheres. What I wanted to conceptualize, in contrast to "critical theory," is that, to the degree the civil sphere remains relatively autonomous, to that degree a society retains the capacity for self-criticism and change. In his recently $A$ performative feel for the game: How meaningful sports shape gender, bodies, and social life, Trygve B. Broch directly confronts "critical theories" of race and gender, arguing that CST is not only morally more uplifting but empirically more faithful to the realities of democratic change. ${ }^{14}$

This is a long way of saying that, no, I do not accept the notion that the discourse of civil society is a colonial discourse; rather, I would say that the discourse of civil society can be used and has been used as a colonial discourse in the same way that it has been used as a racial discourse, as a patriarchal discourse, and as an anti-Semitic discourse but there is always a civil "remainder." That's the whole point of CST, actually. Because the discourse of civil society is binary, it is a very neat and efficient way of justifying domination, and certainly that is one of the most critical points I wanted to make. How, as a Jewish person, I could not help but be hyperaware of this hypocrisy at the heart of Western history. The theoretical implications of the Holocaust began to weigh on me only in the 1970s and early 1980s, as the trauma-drama of the German mass murder began to permeate Western-Christian understandings. It became one more reason for my break with the evolutionary thinking of Parsons.

$A L$ : Could it also be said that critical theorizing in a way is evidence that a civil sphere exists?

$J A$ : Definitely. Critical theory is a way of demanding justice, a way of pointing out that that society is hypocritical, and that actually existing civil spheres are self-serving. If you take classic critical theory from the Frankfurt School, for example Marcuse's work on Hegel, you understand the tension between the universal and the particular as creating a dialectical strain at the heart of society. This is something I agree with entirely, and I believe this makes CST a critical, if not a "critical," theory. Because the civil sphere is always only partially institutionalized, it will inevitably produce "critical" theories. What's fascinating to me is that there will always be new and unexpected forms and foci of critical theory just over the horizon.

$A L$ : You're talking to two ethnographers. What do you think CST could bring to ethnographic work, and how have ethnographic accounts informed your thoughts about CST?

14 Broch, T.B. (2020) A performative feel for the game: How meaningful sports shape gender, bodies, and social life. Cham: Palgrave Macmillan. https://doi.org/10.1007/978-3-030-35129-8 
$J A$ : One of the criticisms of The civil sphere in 2006 was that it didn't look at interaction. There were arguments that it was just a macro theory. Even though it was about institutions and meanings, though, I never thought that the theory couldn't be elaborated to include interactions. My own development of the theory had not gone there, but others could, I believed. So, I would love to see theorists conceptualize the interactional dimension of the civil sphere. The closest thing to cultural sociology that existed, avant la lettre, was ethnography. At Berkeley, and later at UCLA, which had a big ethnographic group, I felt that ethnography was the most fruitful sociological pathway then available for exposing subjectivity in human relationships. What always disappointed me, however, was that it didn't thematize cultural structures. Because of the Chicago tradition, it focused on the emergence of meaning from interactions. I'm aware that there is a circle, with both reproduction and emergence of meaning. The codes of the civil sphere are carried inside of people. They're not just discourse, they are part of emotions and part of identities. Ethnography can show that. Interaction shouldn't be thought of as being irrelevant to the domain of culture or civil sphere. Some excellent ethnographers, like my friends Nina Eliasoph and Paul Lichterman, sometimes seem to suggest that the culture in which interaction is interpellated should be conceived as "style," whereas only the macro level of civil sphere is about codes ${ }^{15}$, but I don't agree.

\section{Applications of civil sphere theory}

$A V$ : In terms of the internationalization of the civil sphere volumes, have these books illuminated anything that surprised you?

$J A$ : Yes, very much so! On the one hand, of course, I have had the satisfaction of affirming my intuition that CST is "true," that it provides a set of universal concepts that can be used productively in all the different places of the world. Yet, at the same time, it's clear that civil spheres are different everywhere. In working on the Latin America book with Carlo Tognato and Nelson Arteaga, for example, I understood the competition between the discourse of civil society and, ideal-typically, two other public discourses that are very visible in Latin America - the patrimonial/hacienda discourse and a militant left discourse, which you might call Leninist or Maoist. If the civil sphere is a sociological theory of democracy, but Latin American nations have, until recently, rarely been democracies, then is CST relevant? What I realized is this: If the civil sphere is a promise, a promissory note, as Martin Luther King put it in "I have a dream," about the expansion of solidarity, then of course there are civil sphere elements in non-democratic societies, in their culture, institutions, and interactions. This collaboration also was important to highlight that the anti-democratic elements that have often hobbled civil spheres in Latin American history have also undermined

15 Eliasoph, N. \& P. Lichterman (2003) "Culture in interaction", American Journal of Socio$\log y 108$ (4):735-794. https://doi.org/10.1086/367920 
civil spheres in the "north" and "west." Fascism was not invented in Latin America, but in Europe, after all.

In The Nordic civil sphere, the big issue for me was the state. I was always very concerned with trying to conceptualize the independence of the civil sphere analytically and empirically from the state, particularly because, in political sociology, we've had such state-centered theories of power and elites. I wanted to emphasize that, if there's a democracy, people go into the state as representatives of the civil sphere. But as we all got into the Nordic project, it became apparent that, if the civil sphere "does well," if civil solidarity becomes strong, then the democratic state can do well, too. Nordic nations have strong states, but they are strong in a civil-democratic way. The idea of the "civil state," to which we dedicate our volume, came from one of our contributors, ${ }^{16}$ and it is a significant new concept. So, working with our collaborators on this volume allowed me to think more clearly about states and civil spheres. And the contributions to The Nordic civil sphere that examine the particularistic and primordial elements that oppose multicultural modes of incorporation gave me more confidence that CST's "modes of incorporation" are applicable outside the US. When I wrote The civil sphere, I was alone, and I often wondered, "Is this true?" Working with many collaborators in the years since the book's publication has not only been exciting and productive, but given me more confidence that, yes, its basic theoretical stipulations hold water.

$A V$ : At this time, there is a global pandemic and also a global movement in support of black lives matter. How can cultural sociology help us understand these times?

$J A$ : We need cultural sociology because it references the inner subjectivity and not just the outer envelope of this movement. You can think of the pandemic as a biological problem, which isn't about cultural sociology. You can also think of it as an emotional and psychological problem, because the feeling of precariousness creates psychological anxiety. You can also think of it sociologically. We could say it's about the class system, about failing medical systems and the structure of governance. As a cultural sociologist, however, I want also to consider the structures of feeling and representation - about what kind of society we feel ourselves to be. The pandemic has raised this question: Are we a good society or not? Do we feel ashamed? Do we have a sustaining civil sphere or is it fragmented and unfair? Are the rich getting well more easily than people in the middle and lower classes? What about the people who, as service workers, provide our essential services, even as they don't have enough medical care to stay healthy, which is especially the case in the United States?

Speaking of the United States, there's been a constant binary discourse of othering and pollution that's allowed people to distance themselves from some COVID-19 victims. There are many Americans who feel they don't have to help the sick, reach out to people in lower classes, stigmatized races, or immigrants. Cultural sociology,

16 Enroth, H. \& M. Henriksson (2019) “The civil sphere and the welfare state”, 15-38 in J.C. Alexander, A. Lund \& A. Voyer (Eds.) The Nordic civil sphere. Cambridge: Polity Press. 
trauma theory, and civil sphere theory have a lot to offer as we try to understand what this crisis means.

And then, on top of the COVID-19 trauma, there was the George Floyd murder. It triggered what American public health guru Anthony Fauci called a "double-whammy" - a play within a play, a trauma within a trauma. It's as if we're looking at a drama about injustice and justice playing out before our very eyes. There is a vast public protest against the inequality of the coronavirus, the inadequacy of our welfare state, racial bias, and structural racism. Yet, at the same time, these protests have become an historic celebration of interracial solidarity, with white Americans supporting them in great numbers. There's been a very pronounced shift in white opinion. If you compare majority white opinion about these current demonstrations to the first Black Lives Matter movement that emerged in 2013, it's remarkable how there's now so much more psychological identification of whites with blacks, and, as a result, a significant cultural extension of civil values. Many observers believe this may be a tipping point in US race relations. The first time around, in 2016, Trump silenced psychological identification and limited cultural extension by winning a racially-tinged election with the support of "All Lives Matter" and "Blue Lives Matter," movements that urged whites to identify with their race and with the police.

As president, Trump continued to denigrate non-whites, women, LGBTI people, and immigrants, and almost immediately the civil sphere struck back. The \#MeToo movement was an extraordinary demonstration of the capacity for expanding justice in the US civil sphere. Trump is a misogynist with a terrible record, but after his election the civil sphere rippled with civil indignation and feminist consciousness, triggering massive, nation-wide protest marches the day after his inauguration. Less than a year after that, we witnessed the massive explosion of an historic social justice movement - \#MeToo. Organized despite, and against, a newly elected American president and his powers of state, \#MeToo and the new movements of racial protest demonstrate the power of cultural structures over material resources, showing how civil power can often trump the power of the state.

I feel some real hope, now, that Trump can be trumped, but of course I don't know what's going to happen.

$A L$ : Both Andrea and myself find some of your concepts from CST very useful, such as civil repair, civil translators, and modes of incorporation. How do you think that these concepts could be applied to current times?

$J A$ : Civil repair depends on identification with those who are suffering, which can happen only if people in the dominant group stop applying the discourse of repression to the dominated, polluting them and justifying their exclusion. This also involves translating their sphere-specific problems into problems for the civil sphere. Only such "societalization" can broaden solidarity. ${ }^{17}$ It is in such a manner that we can repair the

17 Alexander, J.C. (2018) "The societalization of social problems: Church pedophilia, phone hacking, and the financial crisis", American Sociological Review 83 (6):1049-1078. https://doi.org/10.1177/0003122418803376 
consciousness of a compromised civil sphere, which will then direct that state to spend the money and create institutional resources, and to obey shifting legal norms. The current double whammy crisis has exposed civil contradictions as powerfully as ever before. It has created a social drama that provides the opportunity for significantly increasing solidarity and identification.

George Floyd was once an anonymous African American; with the protests, he has become personalized and "known," constructed as a hero, a new personification of injustice. ${ }^{18}$ People now know who George Floyd was. The cover of The New Yorker magazine displayed George Floyd as a giant and beneficent figure, drawing inside this heroic figure smaller dramas about slavery, the civil rights movement, the slave ships coming over. The trauma-drama has allowed identification and cultural extension, and it does give one hope. It's the same process that slowly but surely undermined anti-Semitism after the Holocaust. During the actual mass murder of Jews, and even in its immediate aftermath, there was little identification. It took aesthetic events, like The Diary of Anne Frank and hundreds of melodramatic movies, books, and TV shows about the Holocaust to humanize Jews for Christians, such that they could experience identification and then repulsion for the anti-Semitism that had been previously, for two millennia, accepted in Western society. Only with such a change in consciousness could there begin the dismantling of anti-Semitic laws and institutional policies and the incorporation of Jews into Western society. I hope that this is happening now for African-Americans.

$A L$ : The civil translators can be the activists, but also the media and movies?

$J A$ : The communicative media are critical. While they're reporting the news, they are reconstructing sensibilities and making interpretations. There are also activist carrier groups, civil associations, and public opinion polls. All the different communicative elements are at play.

$A L:$ Are the three modes of incorporation also at play?

$J A$ : Yes. This crisis is all about incorporation. It's not just equality. It's not simply giving and distributing things equally to different groups, which can be thought of as a form of bargaining. Equality is about incorporation into a civil sphere of solidarity. It's about recognition, attachment, and structures of feeling. Empathy, pity, but also alarm, shock, identification, and disgust are all powerful emotions that are circulating and symbolized in the media. But this is also a crisis about a specific, multicultural "mode" of incorporation. Whether it's "only" a new form of political correctness, what it means to incorporate African Americans has shifted over recent weeks. Juneteenth was a holiday, a holy day for African-Americans, but it had been segregated and split off, encapsulated inside the African American

18 Olesen, T. (2015) Global injustice symbols and social movements. New York: Palgrave Macmillan. 
community without the "knowledge" of most in the white community. Suddenly, there's this explosion of discussion about Juneteenth, feeding into growing streams of recognition of African American culture as something dignified and distinctive, with its own rituals and sensibilities. In other words, there's a movement toward framing race inside of the tradition of American pluralism as the pragmatic sociologist Horace Kallen conceived it - as an alternative to melting pot assimilation. You can be incorporated into the American civil sphere and your distinctive differences can actually be increasingly appreciated. That's the fascinating doubleness of this moment.

\section{Reflections on a life in academia}

$A V$ : What are you looking forward to when it comes to your own research?

$J A$ : In 2007, I began to develop a new research program in iconicity. I thought that was what I was going to be writing about for the next few years. I had some fruitful insights and wrote some productive papers. But then I got pulled away by current events. Trauma theory and especially CST are theories about the political world and pressing social problems. They allow me to enter into a thinking relationship with what's going on. That's why you become a sociologist, most people anyway, because you care about society, injustice, conflicts, and reforms. Icon theory is not that kind of theory. It has applications. It can help us understand things that are political, like racial and gender stereotypes, but it's different, not itself a political theory. Rather, it is a theory that highlights the aesthetic - sensuous and material - dimensions of our experience. This iconic dimension can powerfully crystallize gender and race, but it does so in terms of shaping consciousness and emotions about what is beautiful, sublime, ugly, and disgusting. In other words, icon theory adds a new dimension to cultural sociology. For the first time, it intertwines discourse with aesthetics - as practice, as art, as philosophy.

As for where I see my work going: In the first place, I want to continue internationalizing CST - I am currently collaborating with Suryakant Waghmore, a sociologist at the Indian Institute of Technology Mumbai, on an Indian civil sphere project, and with Mervyn Hogan, at the University of Guelph, on the Canadian civil sphere. Ron Eyerman and I have a plan for a project on cultural trauma and the civil sphere, too. I also want to work more continuously on icon theory, which will not only produce foundational concepts about aesthetics and materiality but new approaches to othering and even to contemporary capitalism, which depends on the continuous production of iconically compelling objects.

Down the line, if and when I complete the icon book, I'd also to begin a project about the global civil sphere. Civil spheres have been more, and less, established inside nation-states, but the relation among these states is hardly civilly regulated. Nations maniacally produce weapons and prepare for wars. I see this, in a way, as a problem created by the still limited geographical extension of civil spheres. 
It used to be that civil spheres were confined to city-states, whether these were Greek, medieval, or Renaissance. Then, later, the civil sphere extended to nations. Now, it's what's outside the nation that is a big problem. There is, of course, an "international" discourse of human rights, but there are no global mass media that project representations beyond their nation of origins, e.g., CNN and BBC. The discourse of civil society is globally understood, such that even inside dictatorships corruption can be condemned (though it usually isn't), they feel compelled to have formal voting, constitutions, and newspapers that claim to speak truth. The regulative institutions of the civil sphere don't extend: there is no legal regulation that demands that a global state exercise civil control over violence. Instead, nations that are civilly regulated domestically build weapons of mass destruction and have often fought among themselves terrible wars. So, I'd like to extend civil sphere theory to the world beyond the nation, in a systematic but historically sensitive way. This effort would offer an opportunity to theorize imperialism, in both the West and the East, and the worldwide destruction of the civilizations of indigenous peoples.

$A L$ : In your work, you brought in theories from the humanities and from performance studies as well. Could sociologists learn more from art theory and artistic work?

$J A$ : Sociologists have spent way too much time chasing after what has all too often been the fool's gold of the natural sciences, obsessed with mechanism, force, and statistical significance. As Isaac Reed ${ }^{19}$ so brilliantly explained, there are other approaches to rational social inquiry. If we recognize that meaning is at the center of society and we want to develop a cultural sociology, then we need to look outside our discipline and not to the natural sciences. The significant elements of cultural sociology have come from the humanities or from anthropology - interpretation, narrative, code, performance (and icon). The most important "pure theory" I've developed over the last two decades has been performance theory. In doing so, I didn't draw on Goffman, although he was an inspiration, but from drama and film studies and Austin's notion of performative speech acts. The humanities are about meaning. They deal with reconstructing texts, with how emotions are aroused, and with aesthetic form. Art and life are thoroughly intertwined. So, as I'm working on icon theory, I'm doing a lot of reading in the philosophy of aesthetics and histories of painting and design.

19 Reed I.A. (2011) Interpretation and social knowledge: On the use of theory in the human sciences. Chicago: University of Chicago Press. 
$A L$ : What advice can you offer junior scholars about being a good sociologist?

$J A$ : What moves you from being a young, intellectually-curious person to being a sociologist is learning to translate your social and moral passions into the intellectual language and concepts of the discipline. You shouldn't think of sociology as a science unrelated to your ethical, moral, and even emotional passions. The challenge of doctoral training is to make that movement from here to there in a way that doesn't alienate yourself but, instead, connects it to our intellectual heritage. Sociologists and social theorists have such a tremendous heritage of great minds and great ideas. So, study the things you really care about, but be true to the highest standards of our intellectual traditions. Be honest, but be reflexive. Don't just let your sociology simply write your political beliefs. We have to take one step back. Sociology is politicized and very political, which is great in many ways, but you have to take that one step back. You can't let your immediate reactions to political events be your theory. You know, I hate Trump with a hot passion, but I don't kid myself that our current crisis can be attributed to Trump alone. Replacing him won't change much by itself. He's an expression of the dark side of the American civil sphere, and if we're not able to change that, there will be another Trump in our national future.

$A V$ : You have had a successful career so far, but there were also moments of rejection and uncertainty. What has made it possible to accomplish what you've accomplished?

$J A$ : There's so much shit in the academic world, not to put too fine a point on it. It is so terribly unfortunate that so many creative and intellectually gifted people have been trampled by the academic system. It's a bureaucracy. It's a market. It's filled with routinization and periodically creates enormous frustration. There is real anxiety among our students about finding a job, and, when they do, about publishing furiously, and sometimes strategically, afterward, to get promotion and tenure. Every academic has experienced the frustration of submitting pretty good articles only to have them rejected time and time again! So how do you cope? I think you have to have a project. You need to understand that beneath the bureaucracy and the market is a something deeply meaningful, the sociological equivalent of Henry James' "golden bowl." You have to remember that this bowl is fragile and precious and it's why you got into this "business" in the first place. So, I love writing and I love research and, yeah, there is other stuff that has to be there because otherwise I couldn't be paid for doing the stuff that I love.

The other thing is teaching. Teaching can sometimes feel alienating, but it can also be a transcendental intellectual experience. It's a requirement and you just have to do it, and I've sometimes struggled to stay in touch with the pleasure of teaching. But I'd still wager that few things are more intrinsically satisfying than giving a lecture to receptive university students and to engage in a spirited discussion afterward. And working with engaged doctoral students can truly be a mind-blowing experience. 
$A L$ : What are you most proud of in your academic life?

$J A$ : In terms of a single work, I'd have to say The civil sphere. I wanted to express my sensibility about society as a new sociological theory, but during all the years I worked on CST I never knew whether it would ever be completed, and how it would look, much less how it would be received. But there have also been individual essays in which I have taken deep pleasure and pride. My piece on the Holocaust was intensely meaningful not just personally but intellectually, for I could demonstrate how trauma process could transform injustice into incorporation. My initial essay on social performance, in Sociological Theory, was also a joltingly powerful intellectual experience. In one's life, there are only a handful of moments of deep creativity, and one looks back on them with gratitude.

Then there is the whole collaborative nature of my intellectual experience since the Culture Club first met in my living room in 1984. Ever since, my theorizing has been involved with groups - groups of students, former students who become colleagues, a small set of deeply connected colleagues who never were students, and also the less personal but still vibrant national and international networks that constitute theory and cultural sociology. For the last two decades, all of this has flowed through Yale CCS, which has been the organizational center of my intellectual life, and through the semi-annual conferences of the ISA Social Theory Research Committee. Alone together - I guess that sums up my life as a social theorist. I am filled with gratitude and, really, a sense of wonder, intellectually and personally.

$A L \& A V$ : Thanks for sharing your thoughts and experiences with us. 